\title{
ECOLOGICAL ASPECTS OF THE DISTRIBUTION OF REEF CORALS IN THE NETHERLANDS ANTILLES')
}

\author{
by
}

ROLF P. M. BAK

Caribbean Marine Biological Institute, Curaçao, Netherlands Antilles

\begin{abstract}
The vertical and horizontal patterns of the distribution of corals and coral reefs (to a depth of $90 \mathrm{~m}$ ) are discussed in relation to the environmental factors: geomorphology of the bottom, available substrate, light, turbidity, sedimentation, water movement and temperature. There is a general pattern which is comparable to other well-developed Caribbean reefs. However, as in other areas variations are found, e.g. the depth and growth form of Acropora palmata will depend on the degree of exposure to water movement. There are strong correlations between the environmental variables and the occurrence of coral species and their growth form, the species composition of coral communities and the character of the coral reef. In some cases the relationship is not that obvious. The absence of Agaricia species at certain points along the coast of Aruba and the dominance of Sargassum on the deep bottom at some places along the windward coast of Curaçao is not yet explained.

The relative importance of the different factors in an environmental setting is shown by a comparison of reef communities and reef habitats with a coral community of a muddy, shallow inland bay. The community of the bay consists, apart from the hardier coral species, of corals which are characteristic of the deep reef: Scolymia lacera, S. cubensis and Helioseris cucullata. These corals are adapted to sedimentation and low light intensities and are apparently able to withstand a temperature and salinity range much broader than that of their deep reef habitat.

The paucity of corals and coral reef development around the islands of the Windward Group (deeper habitat included) can generally be explained by the morphology of the sea floor, the lack of suitable substrate and the effect of hurricanes. The exposed coasts of Saba and St. Eustatius, being virtually unexplored, may have richer coral growth.

A new list of species of the Scleractinia of the Leeward and Windward groups, consisting of 57 species, is included.
\end{abstract}

1) Paper presented at the Seventh Caribbean Geological Conference, Section 5: Caribbean Reef Systems, Guadeloupe, 1-5 July 1974.

\section{INTRODUCTION}

The Netherlands Antilles consist of two groups of islands: the Leeward Group of Aruba, Bonaire and Curaçao and the Windward Group of St. Martin, St. Eustatius and Saba (see inset in fig. 1). Most of the research on coral reefs has been done in Curaçao, with some attention being paid to the reefs of Aruba and Bonaire. The marine habitats of the Windward Group are relatively unstudied. The few explorations made, show the Leeward Group of islands to be much richer in reef development (and in species diversity) than St. Martin, St. Eustatius and Saba.

The factors governing coral distribution are well known and include: light, sedimentation, water movement, substrate, bottom morphology and temperature. I will attempt to show how these factors influence the actual distribution of reef corals and coral reefs, vertically and horizontally, in the Netherlands Antilles.

\section{THE REEFS OF THE LEEWARD GROUP}

\section{Vertical distribution}

Goreau \& Wells (1967) noted that the geomorphology of a coast strongly influences the morphology of the coral reef. Although the profiles of the coast are variable, there are a number of general features of the S.W. coasts of Curaçao and Bonaire: a steep cliff or shingle beach, a gradually sloping terrace in front, a drop-off at 7 to $12 \mathrm{~m}$ with a seaward slope varying from $45^{\circ}$ to vertical. This slope may be either continuous or interrupted by an inclined terrace at a depth of 50 to $60 \mathrm{~m}$. There is generally a second vertical drop-off at 70 to $80 \mathrm{~m}$ coming to an end at a sandy plain at 80 to $90 \mathrm{~m}$ (fig. 1). Over this profile there is a 


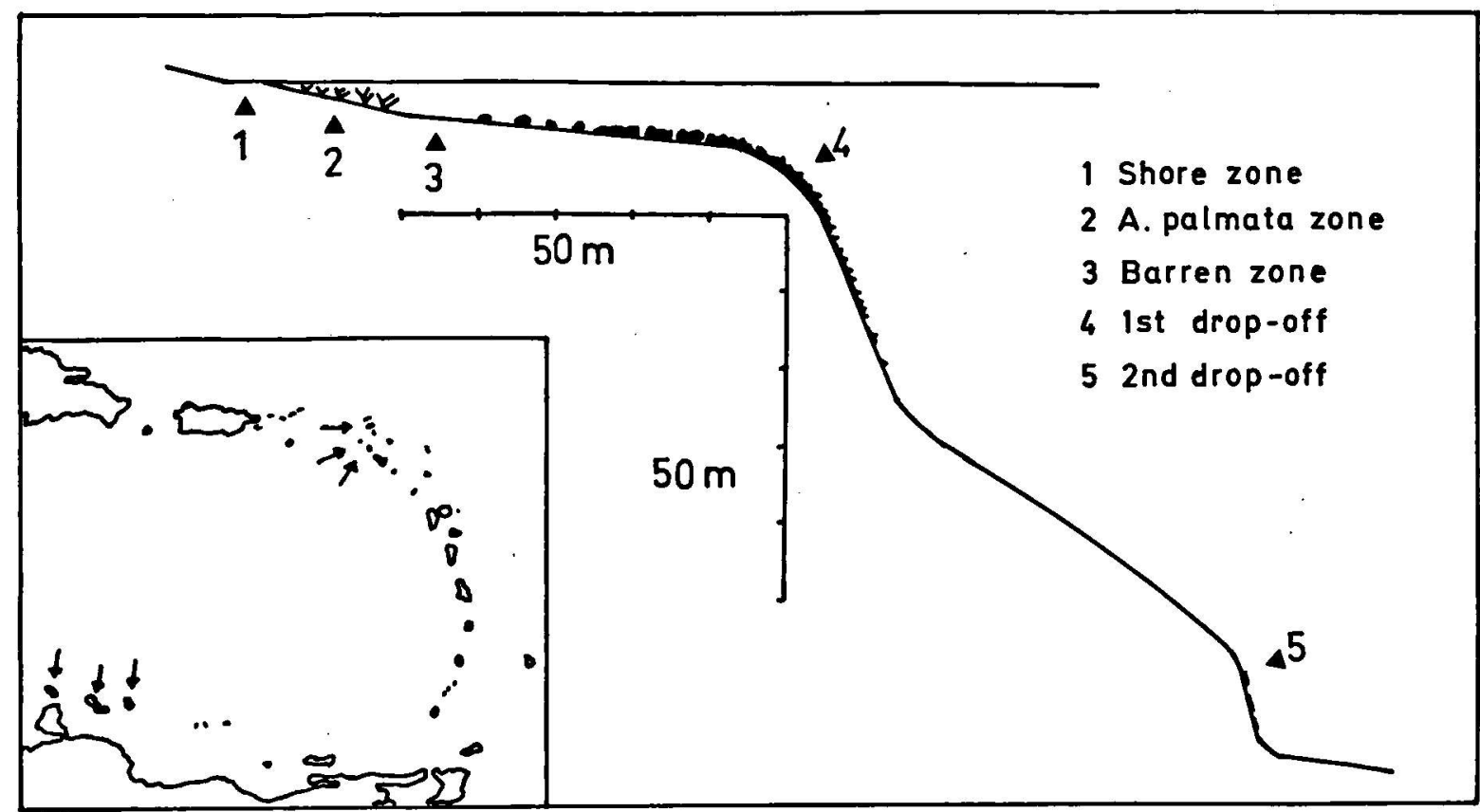

Fig. 1. General profile of the S.W. coasts of Curaçao and Bonaire. The inset shows the geographical position of the Netherlands Antilles in the Caribbean.

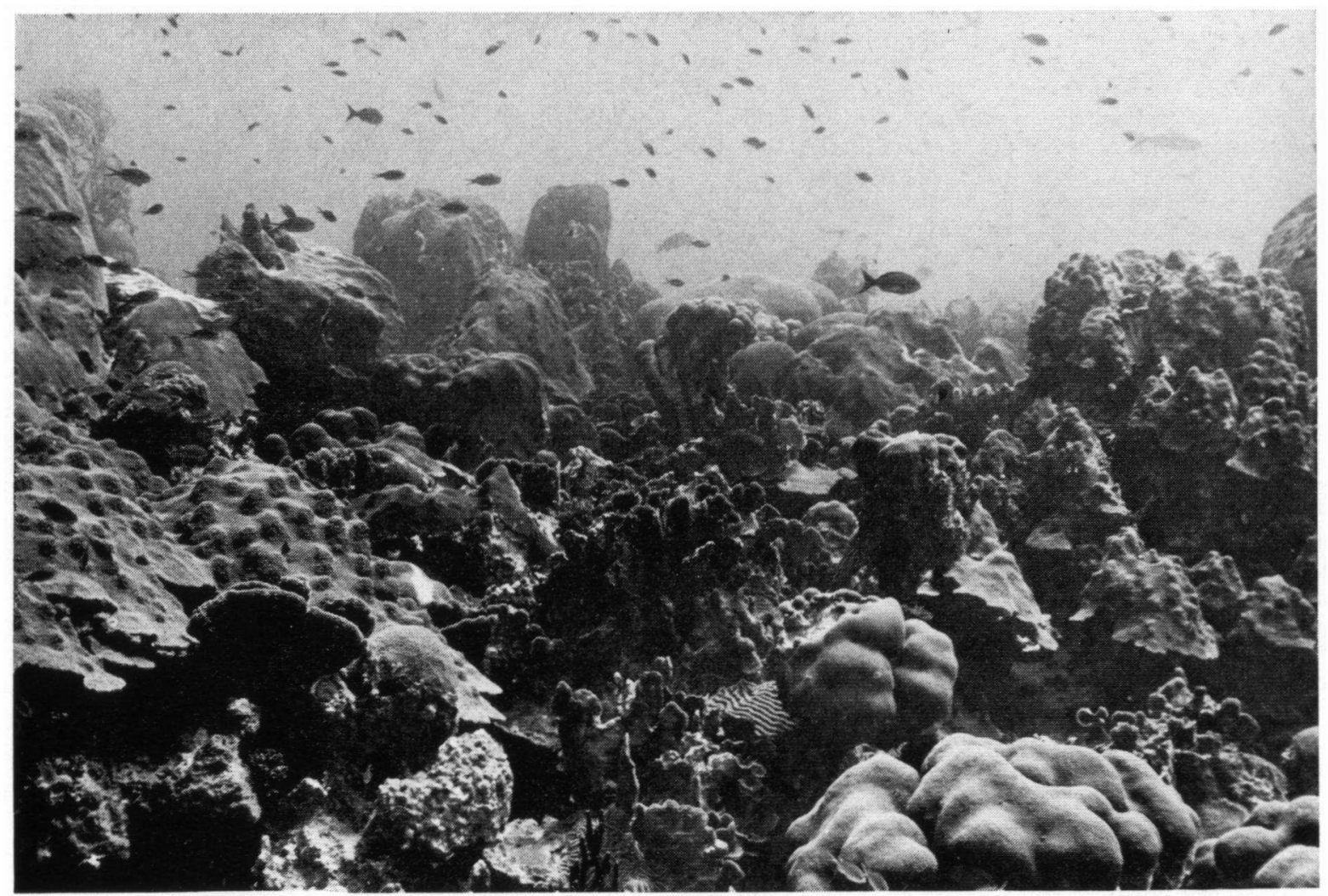

Fig. 2. The reef at the first drop-off $(12 \mathrm{~m})$ on the N.W. coast of Bonaire. Dominant corals are Agaricia agaricites and Montastrea annularis. The latter species occurs in several different growth forms in the same place. 
definite series of coral communities, each one representing a different response to the above-mentioned environmental factors. Of these, temperature is probably not of major influence. Temperature measurements in situ from 10 to $50 \mathrm{~m}$ have never shown a difference over the reef in excess of $2^{\circ} \mathrm{C}$. As the mean monthly temperature at 18 $\mathrm{m}$ depth in Curaçao waters varies from $26^{\circ}$ to $28^{\circ} \mathrm{C}$ throughout the year, temperature never differs significantly from optimum values.

The following reef zones may be recognized: A shore zone, either in front of a shingle beach or in front of a cliff. In the first case, the most conspicuous organisms are algae and echinoderms, while a few encrusting corals will be present. In the latter case, the rock directly under the water surface will be covered with algae, the zoanthid Palythoa mammillosa and encrusting Diploria clivosa. These are areas of heavy stress, subject to strong water movement and occasionally, to partial emergence during low tides. Diploria clivosa is a typical coral of these high energy environments.

From 1 to $4 \mathrm{~m}$ Acropora palmata is by far the most abundant coral and the most important calcium carbonate producer. The growth form of the colonies varies in relation to water movement (Shinn, 1963; Roos, 1964, 1971) from a variety of branched forms to encrusting colonies. In this zone and in the barren zone (the next one seawards) encrusting calcareous red algae (Corallinaceae), especially Porolithon pachydermum (cf. Van den Hoek et al., in press) are of consequence. Their mode of growing over dead coral rubble is important in stabilizing the substrate. In some localities, these algae or Millepora complanata may dominate as reef formers.

The barren zone ( 3 to $4.5 \mathrm{~m}$ ) is devoid of great quantities of reef builders. The substrate oonsists of sand and coral fragments, the latter being mostly dead Acropora palmata branches, partly cemented together by the crustose corallines. Only a few living corals and gorgonians are present. The Acropora palmata zone and the barren zone are both far above the $1 / 2$ normal wave length. The Acropora zone in partioular takes the full force of the waves. After a stormy period (maximum winds up to 36 knots, wind direction parallel to the coast) I examined many broken branches of A. palmata at Jan Thiel (S.W. coast of Curaçao). The largest fracture measured 4 by 30 $\mathrm{cm}$ in section. None of the fractures showed any signs of boring organisms, which shows that the only agent of destruction was the force of the waves. The relatively rapid growth of the A. palmata branches, mean increase in length 6 to $10 \mathrm{~cm}$ a year in situ (Bak, unpublished observations), accomodates greatly the establishment of brokenoff branches as new colonies. Whole colonies, being thrown over, cement themselves to the substrate and start forming new upward branches. In this zone, where settlement of young colonies will be hindered by the scouring of sand over the rocky substrate and the abundance of the grazing sea urchin Diadema antillarum (cf. Bak \& Van Eys, 1975), this mode of "vegetative" reproduction is of particular adaptive value. Also in the barren zone, the scouring of the course sand carried by oscillating water movement over the bottom, will be one of the main factors checking settlement of sessile organisms. In more exposed areas the bottom consists of coral rock and no loose debris is present. In this case, the density of corals and gorgonians is higher.

At 4 to $5 \mathrm{~m}$ the number of coral colonies increases, reaching a great density and diversity in the area before the first drop-off (the blue edge: Roos, 1964) at 6 to $12 \mathrm{~m}$. The bottom in the shallower part is very sandy with isolated coral colonies and gorgonians. Here Acropora cervicornis sometimes forms extensive fields. Towards the drop-off the sandy surface decreases and most of the substrate is living coral and coral rock, covered with a variety of reef organisms (fig. 2). Among the corals, Montastrea annularis, Agaricia agaricites and Madracis mirabilis are most abundant. Calcareous red algae become more prominent again. Except in very rough weather, this area is not influenced by the destruative force of the waves.

Over the drop-off, on the steep slope, high coral density and diversity continues, only to decrease rapidly below $35-40 \mathrm{~m}$. Calcareous red algae are abundant, often preferring the darker crevices of ithe reef, e.g. the important species Hydrolithon boergesenii occurs on the undersides of flattened coral colonies. They are important reef frame cementers and often protect coral surfaces against penetration by boring sponges (Clionidae) (Bak, unpublished observations). On the deeper part of the slope, with diminuation of light intensity, the Corallinaceae become less cryptic and grow on more exposed outcrops. Other sessile organisms show a similar change in microhabitat, e.g. Madracis pharensis. Their place in the holes and crevices of the deep reef is taken over mainly by sponges. This area is rarely influenced by strong water movement, light diminishes rapidly down 


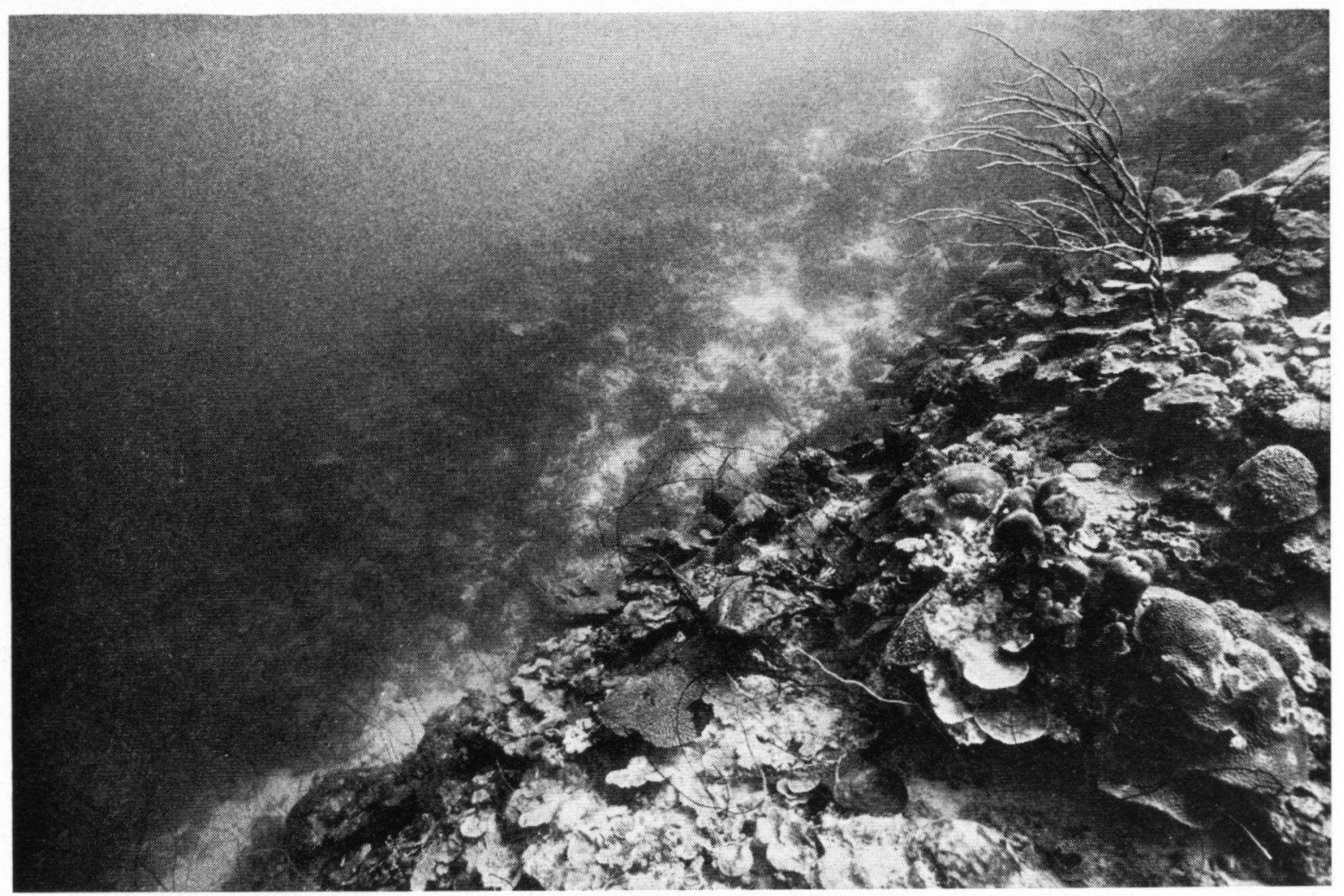

Fig. 3. Alternating coral prominences and sediment rivers at a depth of $20 \mathrm{~m}$ on the S.W. coast of Curaçao.

the slope and there is a strong influence of sodimentation. On this slope sea slides sometimes occur with a width of more than $10 \mathrm{~m}$, scouring the whole slope of organisms. But under normal conditions colonies also break off and roll into deeper water. In addition finer sediments constantly move down the slope. The terrace that may be present from $40-80 \mathrm{~m}$ consists mainly of loose sediments, with some rocky outcrops carrying isolated coral colonies.

Depending on the geomorphology of the bottom, structures have developed resembling the description of the Jamaican fore reef slope (Goreau \& Goreau, 1973). Large coral outcrops growing over the edge of the drop-off are separated by rivers of sediments and loose material, 15-30 m wide (fig. 3). As the sediments flow down along the slope they fan out, inhibiting extensive growth of sessile organisms. Among the corals that penetrate deepest ( $80 \mathrm{~m}$ ) are Montastrea cavernosa and Agaricia undata. The crustose coralline algae are still abundant on the second drop-off at 70 to $80 \mathrm{~m}$.

\section{Horizontal distribution}

The difference in the morphology of the coast together with varied exposure to water movement, available substrate, turbidity and sedimentation are largely responsible for the variations in reef form found in the Netherlands Antilles. On the S.W. coasts of Curaçao and Bonaire these variations are slight. Aside from the vertical differences, there is some decrease in coral cover around bays and the outlets of inland bays. This may be either due to limited settlement of planulae because of sedimentation, reduced growth of colonies because of reduced light intensity, or pollution effects.

The S.W. coast of Aruba is mainly a sandy flat populated with few corals. In some places (e.g. Arashi) the sandy flat changes into a shingle bottom about $1 \mathrm{~km}$ off-shore at a depth of $20 \mathrm{~m}$. On this loose sediment many small coral colonies occur. In other places, where a steeper slope is present, dense Montastrea annularis reefs sometimes develop (Roos, 1971) (fig. 4). Down the slope as sedimentation increases, coral growth decreases until the sandy flat is reached again at a depth of 20 to $30 \mathrm{~m}$. Remarkable and inexplicable is the absence of Agaricia species at the deeper reef in certain areas. Towards the exposed S.E. point of Aruba coral growth is extensive. Here the bottom fauna, characteristic of the shallower zones of 
reefs, occurs deeper. In response to the strong water movement, Millepora species, Agaricia agaricites and gorgonians are very common at a depth of $10 \mathrm{~m}$, all colonies being uniformly oriented in a plane parallel to the wave front. Millepora species form large ridges extending seawards. Other coral colonies are encrusting or flattened.

The N.E. coasts of the islands are, with the exception of a few days a year, subjected to strong trade winds. Normal velocity is $7.2 \mathrm{~m} / \mathrm{sec}$. and persistency is higher than $96 \%$. Reef formation on these coasts varies with morphology of the bottom. The morphology generally follows the same pattern as the S.W. coasts. The most conspicuous difference between leeward and windward coasts is the presence, in the latter, of a submarine platform densely covered with the alga Sargassum platycarpum (cf. Van den Hoek, 1969) in front of the steep shore cliff. On the platform, sloping from $2-6 \mathrm{~m}$ to a drop-off at $10-15 \mathrm{~m}$, coral growth is sparce. It consists mainly of encrusting colonies of Diploria clivosa and Porites astreoides. Acropora palmata occurs in places, but deeper (5-15 m) than on the leeward coast (fig. 5). This agrees with the observations of Glynn (1973) that $A$. palmata grows deeper on the surf beaten coast of the San Blas islands. The sparcity of corals on the terrace may be attributed to the force of the water movements and the relative absence of herbivores (Van den Hoek, 1969; Wanders \& Wanders-Faber, in press). The explored slopes over the drop-off carry a dense coral cover, the species composition resembling the leeward reefs. However, the growth form of the collonies differs from that on the S.W. coast. The corals are encrusting or very flattened, an excoption being the columnar form of Montastrea annularis (fig. 6). Gorgonacea are very abundant. The slope ends at a sandy terrace at $35-45 \mathrm{~m}$; at about $60 \mathrm{~m}$ there is another drop-off. Apant from this deep terrace, nearly no sediments are present.

Important exceptions to this general pattern are found. Near the S.E. point of Curaçao the reef is very much like the exposed S.E. point of Aruba, though it is larger and extends much deeper. The Sargassum community is not found here and the shallow terrace consists of a system of coral grooves and spurs perpendicular to the shore (fig.

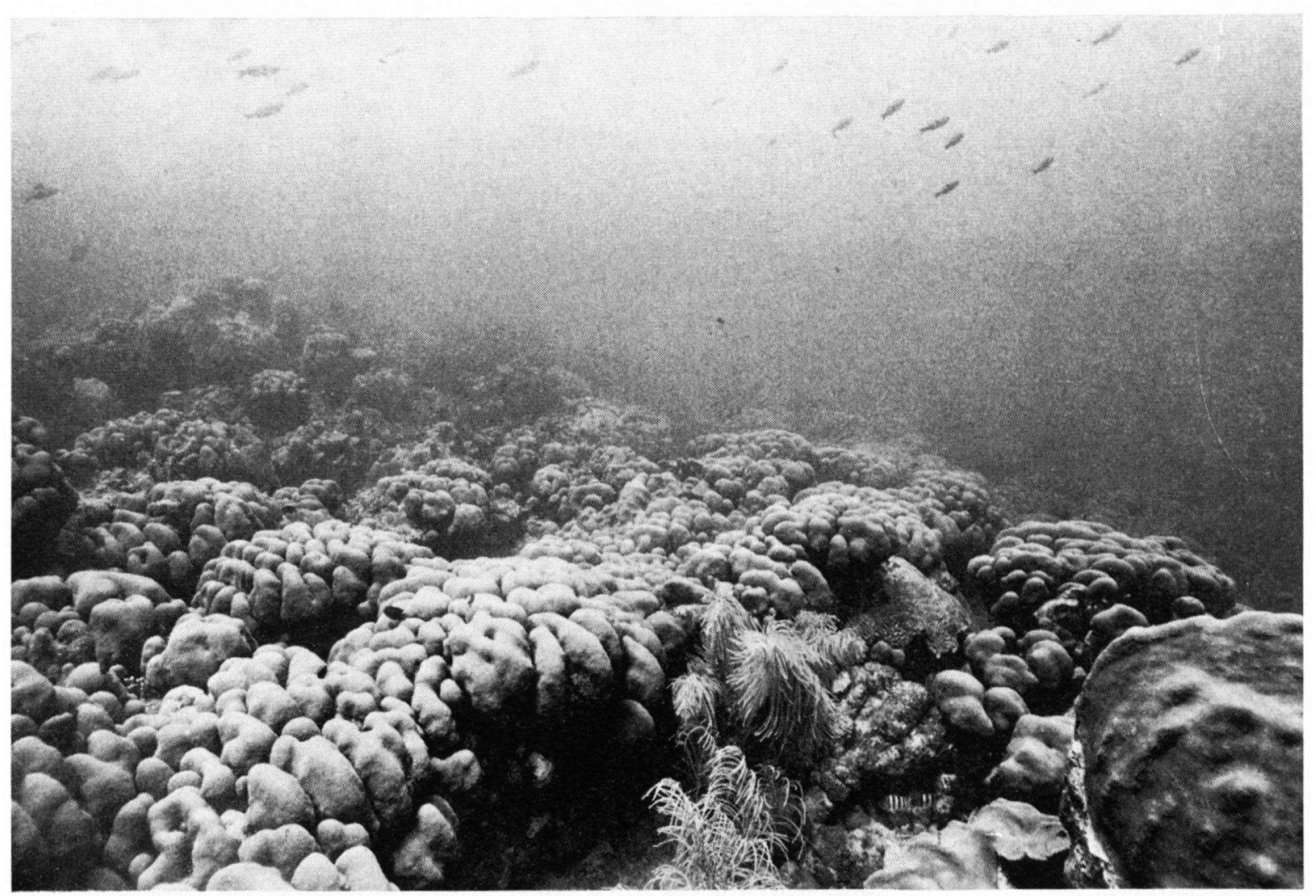

Fig. 4. Montastrea annularis reef at a depth of $10 \mathrm{~m}$ in front of Mangel Altu (Aruba). 
7). There can be little doubt that the influence of eddies and water mixing at the tip of the islands will favor the formation of a coral reef. A few $\mathrm{km}$ farther Northwest along the coast, the Sargassum community covers the bottom again, extending even over the drop-off down to the sandy plain at $35 \mathrm{~m}$. Corals are only found flattened between the algae and crustose corallines are very abundant. Although the bottom is covered with Sargassum platycarpum, close inspection of the substrate shows the algae to be separated by bare rock, with numerous signs of the scraping and biting of herbivores. Still farther to the Northwest, the appearance of the bottom (terrace and slope being covered with algae) abruptly changes again. On the slope, corals suddenly replace the algae resulting in a flourishing coral reef. Since the environmental circumstances are apparently not changing, it is hard to give an explanation. Goreau (1969) attributed such variability to random effects connected with the development of youthful communities. However, as these reefs are very inaccessible, preventing detailed studies so far, these observations are only preliminary.

\section{The relative importance of environmental factors}

A curious example of how environmental factors govern the distribution of corals is shown by comparison of coral population and environmental factors of the deeper reef slope with a large shallow inland bay, Spaanse Water in Curaçao. The similarity was first noted by Roos $(1964,1971)$.

Table I shows the coral community of the bay to be comprised of three components: a shallowwater one, characterized by Favia fragum and Siderastrea radians; a deep-water one with Scolymia lacera, S. cubensis and Helioseris cucullata; and a third group of corals which have a very broad ecological range, e.g. Agaricia agaricites, Porites astreoides, Diploria strigosa and Montastrea cavernosa. This coral community lives on a mud bottom and on mangrove roots at a depth of 1 to $2 \mathrm{~m}$. The water is very quiet. Turbidity is very high and mainly caused by inorganic matter (De Kock \& De Wilde, 1964). The light intensity at a depth of $2 \mathrm{~m}$ is less than $30 \%$ of the surface value. The presence of the hardy shallow-water species is not surprising (Goreau, 1959). The

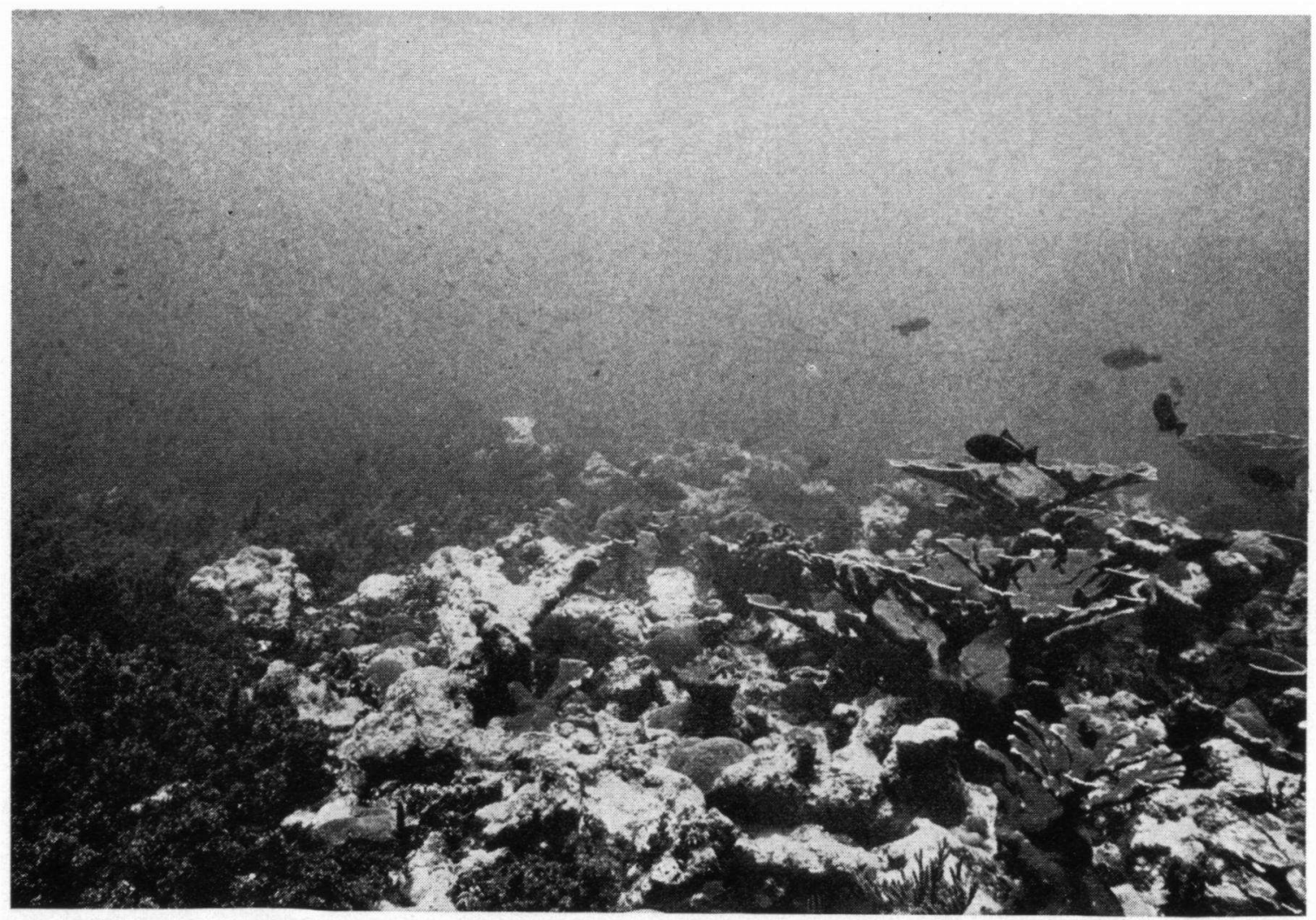

Fig. 5. N.E. coast of Curaçao at a depth of $12 \mathrm{~m}$. The terrace with the Sargassum community is at the drop-off bordered by living and dead Acropora palmata colonies. The dead parts are overgrown with crustose coralline algae. Herbivores apparently prefer grazing on the crustose corallines to feeding on the Sargassum. 
Table I. List of shallow-water Scleractinia of the Netherlands Antilles. Classification mainly after Wells \& Lang (1973).

\section{Class ANTHOZOA \\ Order SCLERACTINIA}

\section{Suborder ASTROCOENIINA}

\section{Family ASTROCOENIIDAE}

L S W 1. Stephanocoenia michelinii Milne Edwards \& Haime, 1848

Family POCILLOPORIDAE

L S W 2. Madracis decactis (Lyman, 1859)

L 3. M. formosa Wells, 1973

L W 4. M. mirabilis (Duchassaing \& Michelotti, 1861)

L 5. M. pharensis (Heller, 1868)

L 6. M. myriaster (Milne Edwards \& Haime, 1849) $\left.{ }^{2}\right)$

L 7. M. senaria Wells, 1973

Family ACROPORIDAE

L W 8. Acropora palmata (Lamarck, 1816)

L S W 9. A. cervicornis (Lamarck, 1816)

L 10. A. prolifera (Lamarck, 1816)

\section{Suborder FUNGIINA}

\section{Family AGARICIIDAE}

$\begin{array}{ll}\text { L S W } & \text { 11. Agaricia agaricites (Linnaeus, 1758) } \\ \text { L } & \text { 12. A. tenuifolia Dana, 1846 } \\ \text { L } & \text { 13. A. undata (Ellis \& Solander, 1786) } \\ \text { L } & \text { 14. A. lamarcki Milne Edwards \& Haime, } 1851 \\ \text { L } & \text { 15. A. grahamae Wells, } 1973 \\ \text { L S } & \text { 16. A. fragilis Dana, } 1846\end{array}$

L S W 17. Helioseris cucullata (Ellis \& Solander, 1786).

Family SIDERASTREIDAE

L S W 18. Siderastrea siderea (Ellis \& Solander, 1786)

L S W 19. S. radians (Pallas, 1766)

Family PORITIDAE

L S W 20. Porites astreoides Lamarck, 1816

L 21. P. branneri Rathbun, 1879

L W 22. P. porites (Pallas, 1766)

L 23. $P$. divaricata Lesueur, 1820

L S W 24. P. furcata Lamarck, 1816

\section{Suborder FAVIINA}

Family FAVIIDAE

L S W 25. Favia fragum (Esper, 1795)

L W 26. Diploria clivosa (Ellis \& Solander, 1786)

L S W 27. D. labyrinthiformis (Linnaeus, 1758)

L S W 28. D. strigosa (Dana, 1846)

L S W 29. Manicina areolata (Linnaeus, 1758)

L S W 30. Colpophyllia natans (Müller, 1775)

L 31. C. breviserialis Milne Edwards \& Haime, 1849

L. W 32. Cladocora arbuscula (Lesueur, 1820)

L S W 33. Montastrea annularis (Ellis \& Solander, 1786)
L S W 34. $M$. cavernosa (Linnaeus, 1766)

L S W 35. Solenastrea bournoni Milne Edwards \& Haime, 1850

Family RHIZANGIIDAE

L W 36. Astrangia solitaria (Lesueur, 1817) ${ }^{3}$ )

L 37. Phyllangia americana Milne Edwards \& Haime, $1850^{3}$ )

L 38. Colangia immersa De Pourtalès, $1871^{3}$ )

Family OCULINIDAE

L 39. Oculina diffusa Lamarck, 1816

Family MEANDRINIDAE

L W 40. Meandrina meandrites (Linnaeus, 1758)

L W 41. Dichocoenia stokesii Milne Edwards \& Haime, 1848

L 42. D. stellaris Milne Edwards \& Haime, 1849

L W 43. Dendrogyra cylindrus Ehrenberg, 1834

Family MUSSIDAE

L W 44. Mussa angulosa (Pallas, 1766)

L S 45. Scolymia lacera (Pallas, 1766)

L S W 46. S. cubensis (Milne Edwards \& Haime, 1849)

L W 47. Isophyllia sinuosa (Ellis \& Solander, 1786)

L W 48. I. multiflora Verrill, 1901

L W 49. Isophyllastrea rigida (Dana, 1846)

L W 50. Mycetophyllia ferox Wells, 1973

L W 51. M. aliciae Wells, 1973

L $\quad$ 52. M. reesi Wells, 1973

\section{Suborder CARYOPHYLLIINA}

Family CARYOPHYLLIIDAE

L 53. Caryophyllia maculata (De Pourtalès, 1874) $)^{4}$ )

L 54. C. sp. cf. C. antillarum De Pourtalès, $\left.\left.1874^{3}\right)^{4}\right)$

L 55. Desmophyllum riisei Duchassaing \& Michelotti, 18603)4)

L S W 56. Eusmilia fastigiata (Pallas, 1766)

Suborder DENDROPHYLLIINA

Family DENDROPHYLLIIDAE

L W 57. Tubastrea coccinea Lesson, 18313)

L Leeward Group

S Spaanse Water

W Windward Group

2) Reported by Roos (1971)

3) Ahermatypic species

*) Reported by Lang (1970) 


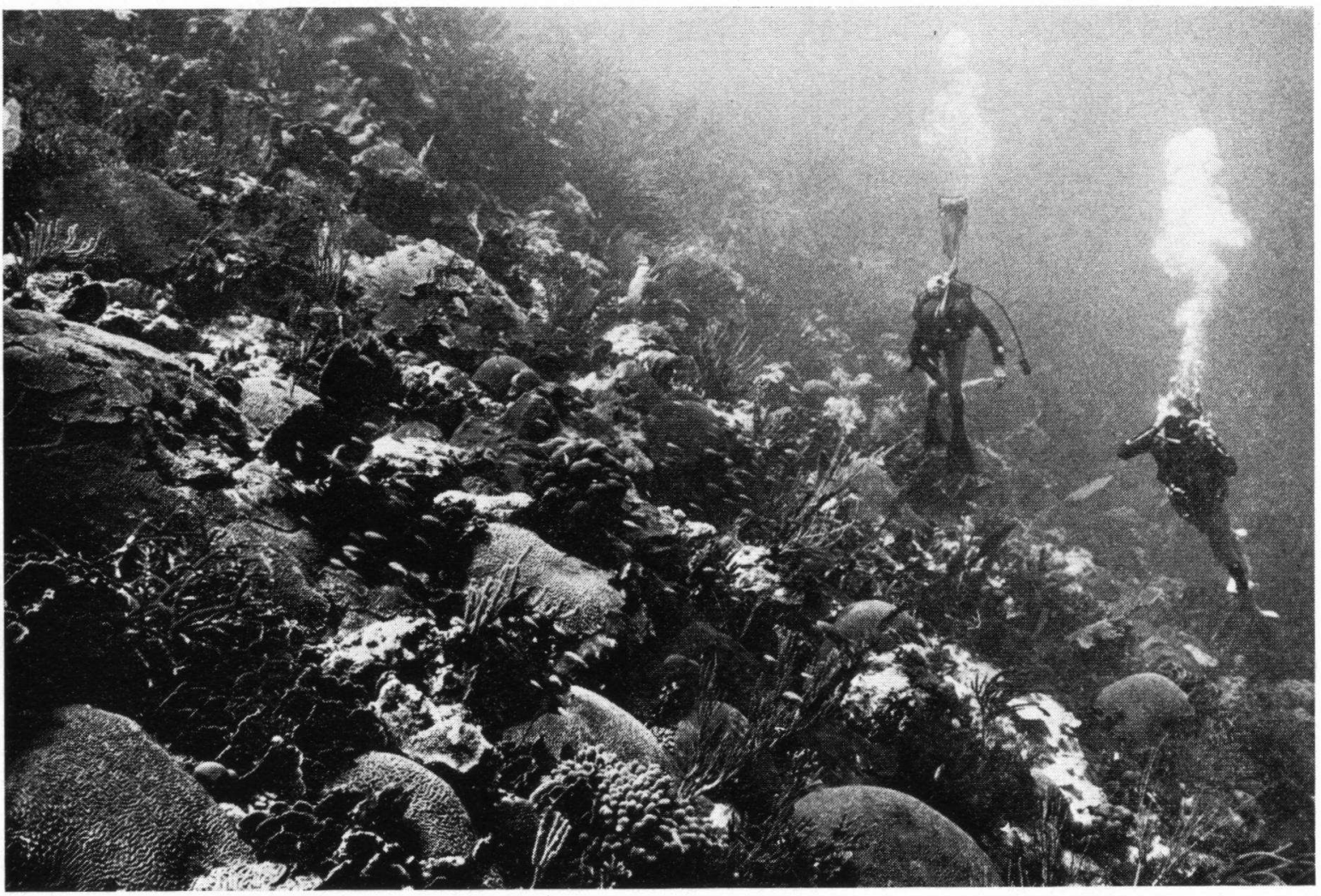

Fig. 6. The slope of a N.E. coast reef in Curaçao at $20 \mathrm{~m}$. The bottom is densely populated with corals and gorgonians. There is nearly no sediment present.

third group of corals can apparently cope with a wide variety of conditions. The group deep-water species clearly requires this light intensity, then it can compete suocessfully with shallow-water species. They can effectively clean themselves of sediments. Their occurrence in the bay shows that they are able to stand a more varied temperature and salinity regime than that of their normal deep water environment.

A group of coral species that is conspicuously absent from the Spaanse Water consists of those species which flourish on the reefs and reef zones exposed to waves and other strong water movements. Typically, Acropora palmata and Dendrogyra cylindrus are missing. This example shows that one should not think of coral species as being adapted to a special place on reefs but indeed to a set of environmental factors.

\section{THE REEFS OF THE WINDWARD GROUP}

The stony corals and their distribution in depth less than $10 \mathrm{~m}$ on St. Martin, St. Eustatius and Saba have boen studied by Roos (1971). Scuba diving to depths of $35 \mathrm{~m}, \mathrm{I}$ found the islands to be surnounded mostly by sandy shallow flats with soattered or no coral growth.

There are some exceptions, e.g. the N.E. point of Saba (Cove Bay). Seawands of a rock zone, a sloping sandy terrace was populated at $30 \mathrm{~m}$ by fields of Acropora cervicornis. These peter out at $35 \mathrm{~m}$ leaving the deeper bottom devoid of corals. The N.W. point of St. Eustatius (Boobies Point) has a steep underwater slope, strewn with huge rocks, ending abruptly in a sand bottom at $30 \mathrm{~m}$. On the slope there is soaittered coral growth and most of the colonlies are encrusting. This is one of the habitats most exposed to waves and currents with good sediment drainage.

Though large areas, especially the exposed coasts, have not been explored, the Windward Group does not seem to have reef development comparable with the reefs of the Leeward Group. Major factors restricting coral reef development are the flat, sandy character of extensive parts of the seafloor and the absence of steep slopes (Goreau \& Wells, 1967). Also, the Windward Group is situated in the Caribbean hurricane belt. Studies on the mechanical effect of hurricanes in the Caribbean have shown their destructive force to be catastrophic to coral reefs (Stoddard, 1963; Glynn 


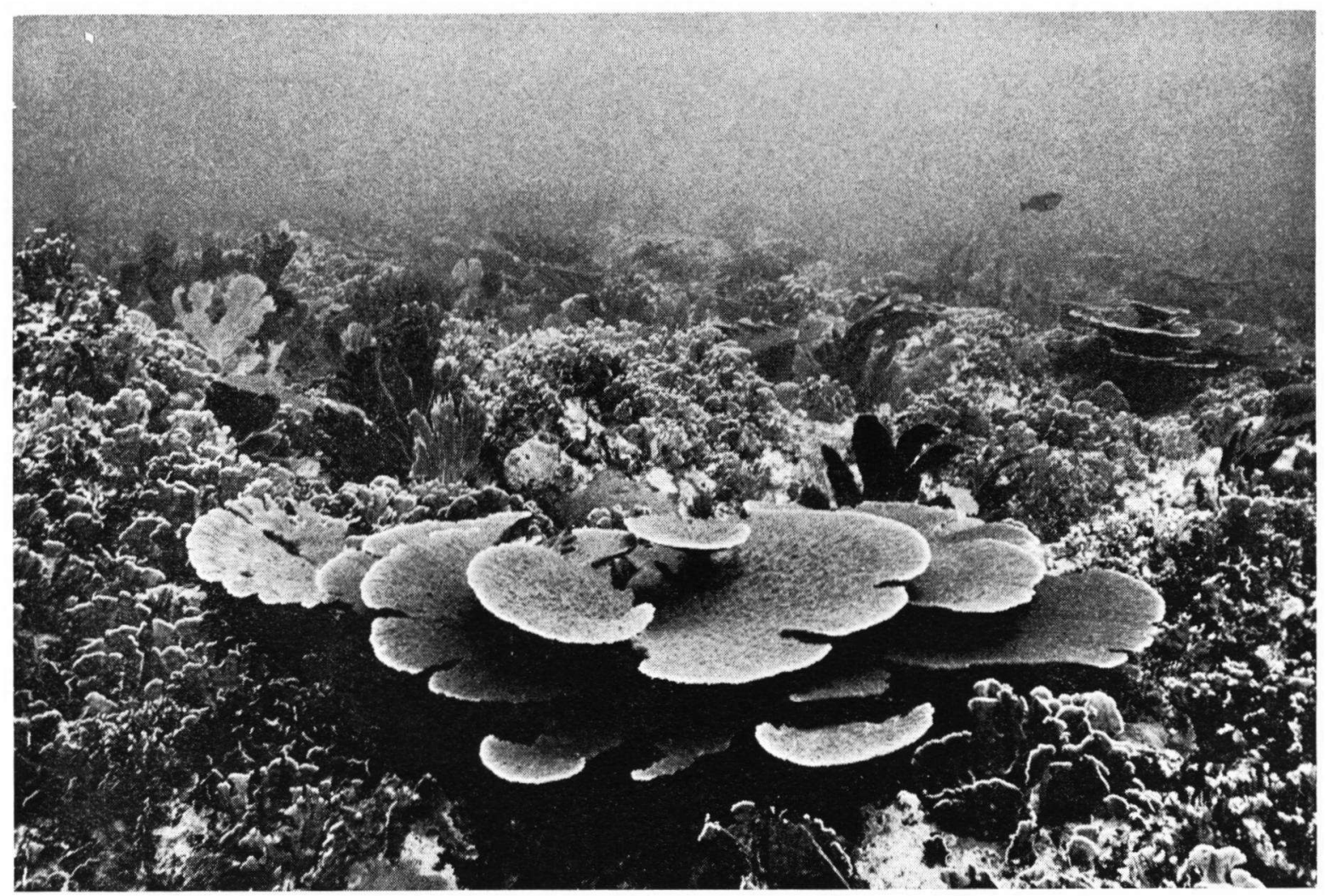

Fig. 7. Near the base of the cliff (depth $5 \mathrm{~m}$ ) on the N.E. tip of Curaçao, the abundance of Gorgonia ventalina, Millepora species and the plate-like growth form of Acropora palmata demonstrate the very rough water conditions of the area. Towards the drop-off a system of grooves and spurs develops.

et al., 1964). These effects seem, however, to be restricted to rather shallow water. Stoddard (1963) observed the coral survival to be much better even at depths as shallow as 7-13 m. He also noted that Acropora cervicornis was the least resistant coral. This is confirmed by Glynn et al. (1964) who report $A$. cervicornis reefs to be completely destroyed. I found healthy $A$. cervicornis fields at $30 \mathrm{~m}$ around Saba. J. van der Land (pers. comm.) mentioned A. cervicornis at depths of less than $15 \mathrm{~m}$ around St. Eustatius and deeper than $17 \mathrm{~m}$ at the Saba Bank. This shows that hurricane effects do not prevent growth of the most sensitive coral at these depths.

\section{CONCLUSION}

It is concluded that the environmental factors discussed are generally regulating the occurrence of corals and coral reefs as well as their morphology. Also the composition of reef communities is strongly dependent on these variables. The factors responsible for the exceptions, such as the lack of reef growth at the N.W. point of St. Eustatius, the alternation of coral reef and Sargassum community and the absence of Agaricia species on some reefs around Aruba, remain to be investigated.

\section{ACKNOWLEDGEMENTS}

I thank my friends at the Caribbean Marine Biological Institute who shared their diving experience. Thanks are also due to the authorities of the Royal Navy in the Netherlands Antilles (in particular to W. B. Donker Curtius) for their cooperation.

\section{REFERENCES}

BaK, R. P. M. \& G. VAN EYS, 1975. Predation of the sea urchin Diadema antillarum Philippi on living coral. Oecologia, 20 (2) : 111-115.

GLYNN, P. W., 1973. Aspects of the ecology of coral reefs in the Western Atlantic region. In: O. A. Jones \& $R$. ENDEAN eds., Biology and geology of coral reefs, II (Biology 1) : 271-324 (Academic Press, New York \& London). 
Glynn, P. W., L. R. Almodovar \& J. G. Gonzalez, 1964. Effects of hurricane Edith on marine life in La Parguera, Puerto Rico. Caribb. J. Sci., 4 : 335-345.

GoreaU, T. F., 1959. The ecology of Jamaican coral reefs. I. Species composition and zonation. Ecology, 40 (1): 67-90.

,- 1969 . Post Pleistocene urban renewal in coral reefs. Micronesica, 5 (2) : 323-327.

Goreau, T. F. \& N. I. Goreau, 1973. The ecology of Jamaican coral reefs. II. Geomorphology, zonation and sedimentary phases. Bull. mar. Sci., 23 (2) : 399464.

GoreaU, T. F. \& J. W. Wells, 1967. The shallow-water Scleractinia of Jamaica: Revised list of species and their vertical distribution range. Bull. mar. Sci., 17 (2) : $442-453$.

HOEK, C. VAN DEN, 1969. Algal vegetation-types along the open coasts of Curaçao, Netherlands Antilles, I. Proc. K. ned. Akad. Wet., (C) 72 (5) : 537-577.

Hoek, C. van den, J. B. W. Wanders \& A. M. CortelBreeman, in press. The role of algae in the coral reef of Klein Piscadera, Curaçao, Netherlands Antilles. Proc. 8th int. Seaweed Symp. Bangor, Wales.
Kock, W. C. DE \& W. J. J. O. DE WILDE, 1964. Verslag over het onderzoek naar de fertiliteit van enige Curaçaose binnenbaaien. Coll. Pap. Caribb. mar. biol. Inst., 4 (51): 1-14.

LANG, J. C., 1970. Interspecific aggression within the scleractinian reef corals (Ph. D. Thesis Yale University, New Haven).

Roos, P. J., 1964. The distribution of reef corals in Curaçao. Stud. Fauna Curaçao, 20 : 1-51, pls. I-XIII.

- , 1971. The shallow-water stony corals of the Netherlands Antilles. Stud. Fauna Curaçao, 37 : 1-108, pls. I-LIII.

ShinN, E. A., 1963. Spur and groove formation on the Florida reef tract. J. sedim. Petrol., 33 : 291-303.

Sroddard, D. R., 1963. Effects of hurricane Hattie on the British Honduras reefs and cays, October 30-31, 1961. Atoll Res. Bull., 95 : 1-142.

Wanders, J. B. W. \& A. Wanders-Faber, in press. Primary productivity of the S.W. coast shallow reef and the N.E. coast brown algae of Curaçao. Br. phycol. J.

Wells, J. W. \& J. C. Lang, 1973. Appendix. Systematic list of Jamaican shallow-water Scleractinia. Bull. mar. Sci., 23 (1) : 55-58.

Received : 10 June 1975 